\title{
Feeding Holstein Cows Exclusively on Well Managed Tropical Grass Pastures ${ }^{1}$
}

\author{
Rubén Caro-Costas and José Vicente-Chandler ${ }^{2}$
}

\begin{abstract}
A herd of Holstein cows fed exclusively on well managed tropical grass pastures in the humid mountain region of Puerto Rico completed 271 lactations over a 2-year period. An average of 3,340 liters of milk/cow/lactation was produced in the first lactation by 185 cows, 176 of which had never before been fed on grass only. The 86 cows that completed 2 lactations during the trial produced an average of 3,535 liters/cow/lactation during the first lactation and 3,826 liters during the second lactation. The average calving interval was $\mathbf{3 9 5}$ days. Cows of low productivity during the first lactation produced markedly higher yields during their section lactation on all-grass rations, whereas the production of the initially higher yielding cows was either sustained or decreased slightly during the second lactation. These results show that cows fed only on well managed tropical grass pastures with no concentrate feeds can produce fairly high yields of milk
\end{abstract}

\section{INTRODUCTION}

Milk production in Puerto Rico depends excessively on expensive imported concentrated feeds. An average of $0.6 \mathrm{~kg}$ of concentrate feed worth 15 cents, is fed per liter of milk produced, much more than in the United States where feed is cheaper and there is a scarcity of good quality forage during winter.

There are approximately 200,000 ha of deep moderately sloping soils well suited to dairying in the humid hill and mountain regions of Puerto Rico. Annual rainfall of about $1,800 \mathrm{~mm}$ is fairly well distributed, and the climate is cooler than in the coastal areas. There are few alternative uses for these lands, since they are not adapted to mechanized crop production and require the protection against erosion that well managed pastures can provide. Furthermore, cattle production in these areas is almost as efficient as on level lands, because land is less expensive, the pastures can be fertilized with special tractors or by air, and the cows harvest their feed by grazing.

Numerous experiments, summarized by Vicente-Chandler et al. ${ }^{3}$, have b en conducted to determine the best methods of managing pastures under typical conditions in the humid hilly and mountainous region of Puerto Rico. Fertilization of Pangola, Star or Napiergrass pastures with

'Manuscript submitted to Editorial Board on November 8, 1978.

${ }^{2}$ Agronomist, cooperative between the Science and Education Administration USDA, and the Agricultural Experiment Station, Mayagüez Campus, and Location Leader-Soil Scientist, Science and Education Administration, USDA, Río Piedras, P.R., respectively.

${ }^{3}$ Vicente-Chandler, J., Abruña, F., Caro-Costas, R., Figarella, J., Silva, S., and Pearson, R. W., Intensive grassland management in the humid tropics of Puerto Rico, Agri. Exp. Stn., Bull. 233, 164 pp, 1974. 
up to $2,200 \mathrm{~kg}$ of $15-5-10 / \mathrm{ha} / \mathrm{yr}$ has been found to be profitable, and grazing of most grasses to a height of about $15 \mathrm{~cm}$ every 3 weeks is about optimum. Well managed pastures of Guinea, Napier, Star or Pangolagrass have carried five head of young cattle/ha throughout the year, producing over 1,000 kg of weight gain/ha/yr. Stargrass pastures have been found to be about 30\% more productive than those of Pangola grass. Recently, Caro-Costas and Vicente-Chandler ${ }^{4}$ found that cows receiving no concentrate feed and grazing Stargrass produced more milk than did those grazing Guinea grass.

In an earlier experiment Caro-Costas and Vicente-Chandler ${ }^{5}$ fed nine Holstein cows exclusively on grass pastures during five consecutive lactations; these cows produced averages of 2,044, 3,696, 3,897, 4,058 and 4,817 liters of milk per lactation, respectively, showing that high yields of milk can be produced by cows grazing on well managed grass pastures with no concentrate feed.

The present study was carried out to determine the effect of feeding a large herd of Holstein cows exclusively on well managed grass pastures with no concentrate feed.

\section{MATERIALS AND METHODS}

The study was carried out on a dairy farm located about $600 \mathrm{~m}$ above sea level. The average annual temperature is $24^{\circ} \mathrm{C}$ with average monthly fluctuations of about $5^{\circ} \mathrm{C}$. The soil is deep red Humatas clay (Ultisol) with an average $40 \%$ slope. Annual rainfall averages about $1,600 \mathrm{~mm}$ fairly evenly distributed throughout the year.

Approximately 74 ha of pastures were divided into 18 enclosures. Each enclosure was provided with fresh water and mineralized salt, grazed for 1 to 2 days, and rested for 3 weeks. About 37 ha were in Star grass, 28 ha in Guinea grass and 9 ha in Napier grass. All the pastures received $550 \mathrm{~kg}$ of $15-5-10 /$ ha every 3 mo. The soil $\mathrm{pH}$ was periodically raised to about 5.5 by liming.

The cows were kept on the pastures at all times except during milking so that they could make full use of the available forage. They were milked twice daily and received only a mixture of bone meal and mineralized salt during milking. They were bred by artificial insemination about 2 mo after calving and were dried about 2 months before calving.

The cows were treated for parasites when they were dried and after calving, they were inspected monthly by a veterinarian to determine pregnancy and to detect and cure diseases. All necessary precautions were taken to reduce mastitis to a minimum.

${ }^{4}$ Caro-Costas, R. and Vicente-Chandler, J., Comparative productivity of intensively managed Star and Guinea grass pastures in terms of milk production in the humid mountain region of Puerto Rico, J. Agri. Univ. P. R. 63 (4): 1979.

${ }^{5}$ Caro-Costas, R. and Vicente-Chandler, J., Milk production by Holstein cows fed only on grass during five consecutive lactations, J. Agri., Univ. P.R., 60 (3): 436-8, 1975. 


\section{RESULTS AND DISCUSSIONS}

The following tabulation shows average monthly rainfall in $\mathrm{mm}$ during the 2-year trial:

\begin{tabular}{lr}
\multicolumn{1}{c}{ Month } & Mm \\
January & 163 \\
February & 38 \\
March & 99 \\
April & 133 \\
May & 114 \\
June & 238 \\
July & 100 \\
August & 119 \\
September & 283 \\
October & 165 \\
November & 236 \\
December & $\underline{208}$ \\
Total & 1,896
\end{tabular}

The initial herd of 185 cows consisted of 44 imported heifers, 25 heifers raised on pastures of an adjacent farm, 45 heifers purchased in various areas of the island, 62 cows of different ages from a dairy on the south coast and nine cows which had been fed only on grass pastures during their previous four lactations. The herd was considered typical of moderately well managed dairies in Puerto Rico. Only four cows were culled and replaced by other cows during the first year, mainly because of unproductive quarters; during the second year 15 cows were culled a yearly average of $16 \%$ of the herd.

During the 2 years, 185 lactations were completed by cows, 176 of which had never before been fed on grass only; and 86 of the same cows completed second lactations for a total of 271 lactations with cows fed exclusively on grass pastures.

Average production for the first 185 lactations on all-grass ration was 3,340 liters/lactation/cow with a 291-day lactation period.

Average production for the first lactation of cows completing two lactations during the course of the trial was 3,329 liters with a 296-day lactation period; and for the second lactation, 3,826 liters/lactation/cow over 282 days.

Table 1 shows that 20 of the imported heifers completed two successive lactations on all-grass rations producing an average of 3,129 liters/cow/ lactation during the first lactation and a significantly higher 3,580 liters during the second lactation. Six of the heifers raised on pastures on an adjacent farm completed two lactations, producing an average of 3,428 
liters during the first lactation and 3,774 liters during the second. Sixteen of the heifers acquired from different dairies completed two lactations, producing an average of 3,074 liters during the first lactation and a significantly higher 3,693 liters during the second lactation. Thirty-two of the cows of different ages completed two lactations producing an average of 3,156 liters during the first lactation and a significantly higher 3,825 liters during the second lactation. The nine cows that had been fed exclusively on grass pastures during their previous four lactations produced an average of 4,817 liters during their fifth lactation and 4,653 liters during their sixth lactation on all-grass rations.

TABLE 1.-Data of the 86 cows which completed two lactations during the course of the trial

\begin{tabular}{|c|c|c|c|c|}
\hline & \multirow{2}{*}{$\begin{array}{l}\text { Number of } \\
\text { cows that } \\
\text { completed } \\
2 \text { lactations }\end{array}$} & \multicolumn{2}{|c|}{ Milk produced } & \multirow{2}{*}{$\begin{array}{l}\text { Calving } \\
\text { interval }\end{array}$} \\
\hline & & $\begin{array}{c}\text { First } \\
\text { lactation }\end{array}$ & $\begin{array}{c}\text { Second } \\
\text { lactation }\end{array}$ & \\
\hline & & Liters/cow & Liters/cow & Days \\
\hline $\begin{array}{l}\text { 1. Heifers imported from Wis- } \\
\text { consin about } 5 \text { months be- } \\
\text { fore calving }\end{array}$ & 20 & $\begin{array}{c}3,129 * * 1 \\
(302)^{2}\end{array}$ & $\begin{array}{r}3,580 \\
(295)\end{array}$ & 401 \\
\hline $\begin{array}{l}\text { 2. Heifers raised on good pas- } \\
\text { tures on an adjacent farm }\end{array}$ & 6 & $\begin{array}{l}3,428 \mathrm{NS}^{1} \\
(297)\end{array}$ & $\begin{array}{l}3,774 \\
(273)\end{array}$ & 376 \\
\hline $\begin{array}{l}\text { 3. Heifers acquired from var- } \\
\text { ious dairies }\end{array}$ & 16 & $\begin{array}{l}3,074^{* *} \\
(296)\end{array}$ & $\begin{array}{l}3,693 \\
(274)\end{array}$ & 384 \\
\hline $\begin{array}{l}\text { 4. Cows of different ages from } \\
\text { a dairy in Salinas }\end{array}$ & 35 & $\begin{array}{l}3,156^{* * *} \\
(287)\end{array}$ & $\begin{array}{c}3,825 \\
(277)\end{array}$ & 403 \\
\hline $\begin{array}{l}\text { 5. Cows fed only on pastures } \\
\text { during their previous } 4 \text { lac- } \\
\text { tations }\end{array}$ & 9 & $\begin{array}{c}4,817 \mathrm{NS} \\
(314)\end{array}$ & $\begin{array}{l}4,653 \\
(294)\end{array}$ & 382 \\
\hline Total & $\begin{array}{l}86 \text { Weighted } \\
\text { average }\end{array}$ & $\begin{array}{l}3,329^{* *} \\
(296)\end{array}$ & $\begin{array}{l}3,826 \\
(282)\end{array}$ & 395 \\
\hline
\end{tabular}

' Differences statistically significant at the $1 \%$ probability level. NS, differences nonsignificant.

${ }^{2}$ Numbers within parentheses show the mean length of the lactations in days.

The 86 cows that completed two lactations during the course of the trial produced an average of 3,329 liters of milk in 296 days during their first lactation, and a significantly higher 3,826 liters in 282 days during their second lactation, with an average calving interval of 395 days.

Table 2 shows that the five cows with the lowest average production (1,874 liters) during their first lactation, significantly increased their yield to an average of 3,670 liters during their second lactation on all-grass rations. The 40 cows which averaged 2,780 liters during their first lactation significantly increased their average production during their second lactation to 3,575 liters. The 22 cows which averaged 3,575 liters during their first lactation averaged 3,810 liters during their second lactation. 
The 14 cows which produced an average of 4,475 liters during their first lactation averaged 4,811 liters during their second lactation on all-grass rations. The 5 cows with the highest average yields (5,698 liters) during their first lactation on all-grass rations significantly decreased their production during their second lactation to an average of 4,423 liters.

The cows varied widely in production during their first lactation on allgrass rations from an average of 1,864 liters for the group of the five lowest producing cows to 5,698 liters for the group of the five highest yielding cows. During the second lactation, however, production varied much less (from an average of 3,575 to 4,811 liters/cow for the five groups) with the previously low yielding cows increasing their production and the initially higher yielding cows either maintaining or decreasing their production.

TABLE 2.-Milk produced during the first and second lactation by cows grouped according to production during the first lactation

\begin{tabular}{cccc}
\hline $\begin{array}{c}\text { Number of cows } \\
\text { in range } \\
\text { of } \\
\text { production } \\
\text { indicated }\end{array}$ & $\begin{array}{c}\text { Range of } \\
\text { production } \\
\text { during first } \\
\text { lactation }\end{array}$ & $\begin{array}{c}\text { Average } \\
\text { production } \\
\text { during first } \\
\text { lactation }\end{array}$ & $\begin{array}{c}\text { Average } \\
\text { production } \\
\text { during second } \\
\text { lactation }\end{array}$ \\
\hline 5 & Liters & Liters & Liters \\
40 & $1,591-2,273$ & $1,864^{* * 1}$ & 3,670 \\
22 & $2,273-3,182$ & $2,780^{* *}$ & 3,575 \\
14 & $3,182-4,091$ & $3,575 \mathrm{NS}$ & 3,810 \\
5 & $4,091-5,000$ & $4,465 \mathrm{NS}$ & 4,811 \\
\hline
\end{tabular}

${ }^{1}$ Differences are significant at the $1 \%$ probability level. NS, difference nonsignificant.

The following tabulation shows the quantity of millk produced during the first and second lactations by cows from different origins compared to that produced by nine cows in a previous study by Caro and VicenteChandler ${ }^{6}$; in all cases the cows were fed exclusively on grass.

Average liters of milk/lactation/cow

$\begin{array}{cc}\text { First } & \text { Second } \\ \text { lactation } & \text { lactation }\end{array}$

20 heifers imported from 3,129 3,580

Wisconsin

16 heifers from different

3,074

3,693

dairies in P.R.

6 heifers raised on grass

3,428

3,774

pastures at Orocovis

9 heifers fed exclusively

2,044

3,696

on grass for 6 successive lactations 
Although there was considerable variation in production among the four groups of cows during their first lactation on an all-grass ration, production during their second lactation was very similar for all groups. The nine cows used in the study by Caro-Costas and Vicente-Chandler ${ }^{6}$ produced 3,897, 4,058, 4,817 and 4,653 liters during their subsequent four lactations, respectively.

Table 3 shows average monthly milk production during the two consecutive years of the study. During the first year an average of 148.4 cows in the milking herd produced a total of 548,179 liters of milk or an average

TABLE 3.-Average monthly production of milk during two consecutive years by the herd of Holstein cows fed only on tropical grass pastures

\begin{tabular}{|c|c|c|c|c|c|c|}
\hline \multirow[b]{2}{*}{ Month } & \multicolumn{3}{|c|}{1974} & \multicolumn{3}{|c|}{1975} \\
\hline & $\begin{array}{c}\text { Cow-days } \\
\text { of } \\
\text { milking }\end{array}$ & $\begin{array}{l}\text { Liters } \\
\text { produced }\end{array}$ & $\begin{array}{l}\text { Liters } \\
\text { produced/ } \\
\text { cow/day }\end{array}$ & $\begin{array}{c}\text { Cow-days } \\
\text { of } \\
\text { milking }\end{array}$ & $\begin{array}{c}\text { iters } \\
\text { produced }\end{array}$ & $\begin{array}{c}\text { Liters } \\
\text { produced/ } \\
\text { cow/day }\end{array}$ \\
\hline Jan. & 3,423 & 37,664 & 11.00 & 4,085 & 42,980 & 10.52 \\
\hline Feb. & 3,842 & 42,019 & 10.94 & 3,934 & 44,530 & 11.32 \\
\hline Mar. & 4,475 & 54,796 & 11.48 & 4,451 & 50,518 & 11.37 \\
\hline Apr. & 4,943 & 58,575 & 11.73 & 4,170 & 47,817 & 11.47 \\
\hline May & 4,998 & 51,960 & 10.40 & 4,245 & 50,560 & 11.91 \\
\hline Jun. & 5,090 & 50,903 & 10.18 & 4,533 & 49,710 & 10.97 \\
\hline Jul. & 5,035 & 50,555 & 10.04 & 4,789 & 54,955 & 11.48 \\
\hline Aug. & 4,792 & 47,507 & 9.91 & 4,759 & 54,220 & 11.39 \\
\hline Sept. & 4,523 & 46,128 & 10.20 & 4,491 & 42,937 & 9.56 \\
\hline Oct. & 4,234 & 37,052 & 8.75 & 4,398 & 44,066 & 10.02 \\
\hline Nov. & 4,504 & 34,540 & 7.67 & 4,244 & 42,797 & 10.08 \\
\hline Dec. & 3,997 & 36,480 & 9.13 & 4,235 & 42,810 & 10.11 \\
\hline Total & 54,156 & 548,179 & - & 52,334 & 568,000 & - \\
\hline Average & $148.4^{1}$ & 45,682 & 10.12 & $143.4^{*}$ & 47,333 & 10.85 \\
\hline
\end{tabular}

${ }^{1}$ Average number of cows milked daily.

of $10.12 \mathrm{~L} /$ cow. During the second year an average of 143.4 cows in the milking herd produced a total of 568,000 liters of milk or an average of $10.85 \mathrm{~L} /$ cow. Production was generally lower from September through February and highest from March through August.

Average calving interval for all cows in the herd was 390 days which compares favorably with an average of 450 days for DHIA herd in Puerto Rico. Mastitis was not an important problem, with rarely more than two cows affected monthly. Bacterial counts in the milk ranged from 10,000 to $50,000 / \mathrm{ml}$.

Fat content of the milk ranged from 3.5 to $3.7 \%$, which compares favorably with an average of $3.0 \%$ for DHIA and first class dairies in Puerto Rico in which cows receive abundant concentrate feed.

${ }^{6}$ Caro-Costas, R. and Vicente-Chandler, J., Milk production by Holstein cows fed only on grass during five consecutive lactations, J. Agri. Univ. P.R., 60 (3): 436-8, 1975. 
An average of 185 milking and dry cows were maintained on the 74 ha of pastures. They produced 555,000 liters of milk yearly or an average of $7,500 \mathrm{~L} / \mathrm{ha} / \mathrm{yr}$. Assuming that 37 ha more are required for grazing replacement heifers, each hectare of good pastures, in the land typical of the 200,000 ha in the humid hilly and mountainous regions of Puerto Rico, could produce the equivalent of 5,000 liters of milk/ha/yr with no concentrate feeds. Thus, the Island's present consumption of fresh milk could be produced on 80,000 ha of good pastures without concentrate feed. At present 320,000 tons of concentrate feeds are imported yearly at a cost of about $\$ 64$ million. In addition, good use would be made of sloping lands with few alternative uses.

The data presented in this paper corroborate previous findings by the authors that at least 10 liters of milk can be produced daily by cows fed only on good pastures on these sloping lands in the humid region of Puerto Rico. However, with high yielding cows, $.45 \mathrm{~kg}$ or more of concentrate should be fed for each additional liter of daily milk production, the exact quantity depending on each cow's production.

\section{RESUMEN}

Todas las vacas en una lechería en la región montañosa húmeda de Puerto Rico se alimentaron exclusivamente con pastos bien cultivados y abonados durante un periodo de 2 años.

Se completaron 185 lactancias con vacas que nunca se habian alimentado con pastos solamente, y 86 segundas lactancias de las mismas vacas para un total de 271 lactancias. La producción media de las 185 lactancias iniciales fue de 3,340 litros; y 3,826 litros la de las 86 segundas lactancias.

Las vacas que produjeron menos en la primera lactancia aumentaron señaladamente su producción en la segunda mientras que las de más alta producción inicial mantuvieron o bajaron su producción en la segunda lactancia tendiendo así a uniformar la producción.

El intervalo medio entre partos fue de 390 días. La mastitis no constituyó un problema de importancia y el contenido de bacterias varió de 10,000 ó $50,000 / \mathrm{ml}$, lo cual compara favorablemente con el requisito del gobierno federal de no más de 100,000 bacterias $/ \mathrm{ml}$.

El contenido de grasa de la leche fluctuó de 3.5 a $3.7 \%$, el cual compara favorablemente con alrededor de $3 \%$ en las vaquerías de primera clase en Puerto Rico, que utilizan cantidades excesivas de alimento concentrado.

Aunque se podría producir el consumo actual de leche fresca de la Isla en unas 80,000 hectáreas de buenos pastos sin usar alimento concentrado, lo más deseable es depender de pastos bien cultivados y abonados para producir los primeros 10 litros de leche de producción diaria por vaca, usando $0.45 \mathrm{~kg}$ o más de alimento concentrado por cada litro adicional, dependiendo de la producción de la vaca. 